\title{
Matrix metalloproteinase 9 inhibits the motility of highly aggressive HSC-3 oral squamous cell carcinoma cells
}

\section{Vayrynen, Otto}

2019-03-01

Vayrynen , O , Astrom , P , Nyberg , P , Alahuhta , I , Pirila , E , Vilen , S-T , Aikio , M , Heljasvaara , R, Risteli , M , Sutinen , M \& Salo , T 2019 , ' Matrix metalloproteinase 9 inhibits the motility of highly aggressive HSC-3 oral squamous cell carcinoma cells ' , Experimental Cell Research, vol. 376 , no. 1 , pp. 18-26 . https://doi.org/10.1016/j.yexcr.2019.01.018

http://hdl.handle.net/10138/313334

https://doi.org/10.1016/j.yexcr.2019.01.018

unspecified

publishedVersion

Downloaded from Helda, University of Helsinki institutional repository.

This is an electronic reprint of the original article.

This reprint may differ from the original in pagination and typographic detail.

Please cite the original version. 


\title{
Matrix metalloproteinase 9 inhibits the motility of highly aggressive HSC-3 oral squamous cell carcinoma cells
}

\author{
Otto Väyrynen $^{\mathrm{a}, \mathrm{b}, 1}$, Pirjo Åström ${ }^{\mathrm{a}, \mathrm{b}, 1}$, Pia Nyberg ${ }^{\mathrm{a}, \mathrm{b}, \mathrm{c}}$, Ilkka Alahuhta ${ }^{\mathrm{a}, \mathrm{b}}$, Emma Piriläa,b \\ Suvi-Tuuli Vilen $^{\mathrm{d}}$, Mari Aikio $^{\mathrm{e}}$, Ritva Heljasvaara ${ }^{\mathrm{e}, \mathrm{f}}$, Maija Risteli ${ }^{\mathrm{a}, \mathrm{b}, 1}$, Meeri Sutinen $^{\mathrm{a}, \mathrm{b}, 1}$, \\ Tuula Salo ${ }^{\mathrm{a}, \mathrm{b}, \mathrm{d}, \mathrm{g}, *, 1}$ \\ ${ }^{a}$ Cancer and Translational Medicine Research Unit, Faculty of Medicine, University of Oulu, Oulu, Finland \\ ${ }^{\mathrm{b}}$ Medical Research Center Oulu, Oulu University Hospital, University of Oulu, Oulu, Finland \\ ${ }^{\mathrm{c}}$ Biobank Borealis of Northern Finland, Oulu University Hospital, Finland \\ ${ }^{\mathrm{d}}$ Department of Oral and Maxillofacial Diseases, University of Helsinki, Helsinki, Finland \\ e Oulu Center for Cell-Matrix Research and Biocenter Oulu, Faculty of Biochemistry and Molecular Medicine, University of Oulu, Finland \\ ${ }^{\mathrm{f}}$ Centre for Cancer Biomarkers (CCBIO), University of Bergen, Norway \\ ${ }^{\mathrm{g}}$ HUSLAB, Department of Pathology, Helsinki University Central Hospital, University of Helsinki, Helsinki, Finland
}

\section{A R T I C L E I N F O}

\section{Keywords:}

Matrix metalloproteinase 9

CTT2

Arresten

Tumour microenvironment

Invasion

Organotypic model

\begin{abstract}
A B S T R A C T
Pro-tumorigenic activities of matrix metalloproteinase (MMP) 9 have been linked to many cancers, but recently the tumour-suppressing role of MMP9 has also been elucidated. The multifaceted evidence on this subject prompted us to examine the role of MMP9 in the behaviour of oral tongue squamous cell carcinoma (OTSCC) cells. We used gelatinase-specific inhibitor, CTT2, and short hairpin (sh) RNA gene silencing to study the effects of MMP9 on proliferation, motility and invasion of an aggressive OTSCC cell line, HSC-3. We found that the migration and invasion of HSC-3 cells were increased by CTT2 and shRNA silencing of MMP9. Proliferation, in turn, was decreased by MMP9 inhibition. Furthermore, arresten-overexpressing HSC-3 cells expressed increased levels of MMP9, but exhibited decreased motility compared with controls. Interestingly, these cells restored their migratory capabilities by CTT2 inhibition of MMP9. Hence, although higher MMP9 expression could give rise to an increased tumour growth in vivo due to increased proliferation, in some circumstances, it may participate in yet unidentified molecular mechanisms that reduce the cell movement in OTSCC.
\end{abstract}

\section{Introduction}

Oral tongue squamous cell carcinoma (OTSCC) is globally the most frequent type of oral cancer in terms of epidemiology [1]. It is a highly aggressive cancer associated with a low rate of local tumour control, and, despite advances in diagnostics and therapeutics, the 5-year survival rate remains low, around $60 \%[2]$.

Matrix metalloproteinases (MMPs) are, in general, considered key players in cancer progression due to their capability to degrade tissue barriers, allowing tumour cells to invade and metastasize. However, MMPs have far more complex roles in cancer, and some MMPs are now also shown to suppress some aspects of cancer progression [3].

MMP9 has conventionally been considered as a pro-tumorigenic enzyme in oral squamous cell carcinoma (OSCC). A recent meta-analysis study showed that MMP9 overexpression is a predictor of poor prognosis in OTSCC patients [4]. However, whether MMP9 expression in the most aggressive tumours enhances tumour progression or is more a consequence of tumour aggressiveness is unknown. Previous studies have revealed both pro- and anti-tumorigenic roles of MMP9 (reviewed in detail by Vilen et al. [5]), and its role in oral cancer is far from clear [5]. Jordan et al. [6] found that the mRNA levels of MMP9 were significantly higher in oral dysplasias that progressed to oral cancer than in those that did not [6]. Pro- and active forms, total activities and the activation ratio of MMP9 were also significantly elevated in OSCC samples compared with their adjacent areas histologically rated as normal tissues [7]. In contrast, Stokes et al. [8] showed that MMP9 mRNA in primary tumours compared with adjacent peritumoral tissues was significantly decreased in head and neck squamous cell carcinomas with lymph node metastasis compared with non-metastatic tumours [8]. Moreover, Lin et al. [9] demonstrated that although patients with

\footnotetext{
* Corresponding author at: Cancer Research and Translational Medicine Research Unit, Faculty of Medicine, University of Oulu, P.O. Box 8000, FI-90014, Finland. E-mail address: tuula.salo@oulu.fi (T. Salo).

${ }^{1}$ Equal contributions.
} 
OSCC exhibit significantly higher levels of MMP9 than healthy controls, and even though MMP9 plasma levels are associated with more advanced clinical stages, MMP9 level was not associated with positive lymph node or distal metastasis [9]. Evidence for the oncosuppressive role of MMP9 has also emerged for other cancers such as colitis-associated cancers [10] and breast cancer when MMP9 is produced by cancer cells [11].

Recently, we have reported increased MMP9 expression in HSC-3 clone overexpressing MMP8 with decreased migration and invasion [12]. Additionally, although anti-MMP2 and -9 peptides inhibit tongue carcinoma growth $[13,14]$ and angiogenesis [13], they do not prevent the spread of carcinoma cells in nude mice [14]. Instead, when antiMMP2 and -9 peptides were used in combination with proMMP9 targeting therapy, increased HSC-3 tumour growth was observed in mice [14].

This study aims to elucidate the role of MMP9 in the behaviour of aggressive oral tongue carcinoma cells in vitro by using various genetically modified cell models with altered MMP9 expression as well as inhibition of MMP9 by gelatinase (MMP2 and -9) inhibitor peptide CTT2 [15].

\section{Materials and methods}

\subsection{Cell culture}

\subsubsection{Native cell lines}

Human tongue squamous cell carcinoma cell lines HSC-3 (Japanese Collection of Research Bioresources (JCRB) Cell Bank, JCRB0623), SAS (JCRB Cell Bank, JCRB0260), SCC-25 (American Type Culture Collection (ATCC), CRL 1628), human malignant melanoma G361 (ATCC, CRL-1424) and human Caucasian breast adenocarcinoma cell line MDA-MB-231 (ATCC, HTB-26) were cultured in Dulbecco's modified Eagle's medium (DMEM)/F-12, 1:1 (Gibco) supplemented with $10 \%$ heat-inactivated foetal bovine serum (FBS, Gibco), $50 \mu \mathrm{g} / \mathrm{ml}$ ascorbic acid, $100 \mathrm{U} / \mathrm{ml}$ penicillin, $100 \mu \mathrm{g} / \mathrm{ml}$ streptomycin, $250 \mathrm{ng} / \mathrm{ml}$ amphotericin B and $0.4 \mu \mathrm{g} / \mathrm{ml}$ hydrocortisone (all from Sigma-Aldrich). Human embryonic kidney cell HEK-293 (ATCC, CRL-1573), human gingival fibroblasts (GFs) and human spontaneously immortalized keratinocytes (HaCaT) [16] were cultured in DMEM (Sigma-Aldrich) supplemented with $10 \%$ heat-inactivated FBS, $100 \mathrm{U} / \mathrm{ml}$ penicillin, $100 \mu \mathrm{g} / \mathrm{ml}$ streptomycin, $50 \mu \mathrm{g} / \mathrm{ml}$ ascorbic acid, $250 \mathrm{ng} / \mathrm{ml}$ amphotericin B and $1 \mathrm{mM}$ sodium pyruvate (all from Sigma-Aldrich). GFs used in this study were obtained from biopsies of healthy gingiva as described earlier [17]. The human papillomavirus HPV16 immortalized human oral epithelial cells (IHGK) [18] were cultured in KeratinocyteSFM (Gibco) supplemented with $5 \mathrm{ng} / \mathrm{ml}$ human recombinant epidermal growth factor, $50 \mu \mathrm{g} / \mathrm{ml}$ bovine pituitary extract (both from Gibco), $100 \mathrm{U} / \mathrm{ml}$ penicillin, $100 \mu \mathrm{g} / \mathrm{ml}$ streptomycin, $250 \mathrm{ng} / \mathrm{ml} \mathrm{am-}$ photericin B and $100 \mu \mathrm{M} \mathrm{CaCl}_{2}$ (all from Sigma Aldrich). Information on the native cell lines used in this study is presented in Supplementary Table S1.

\subsubsection{Transduced and transfected cell lines}

HSC-3 and SAS cells were stable transduced with three different commercial human GIPZ MMP9 lentiviral shRNAmir particles (Thermo Fischer Open Biosystems) according to the manufacturer's instructions with puromycin (Sigma-Aldrich) selection. HSC-3 cells transduced with the non-silencing scrambled GIPZ lentiviral shRNAmir particles (Thermo Fischer Open Biosystems) were used as a control cell line (control HSC-3 cells) MMP9 silencing was confirmed by semi-quantitative PCR and zymography, and the expression level of MMP9 in conditioned media of shMMP9 and control cells was regularly tested before experiments by zymography (described below). HSC-3 cells with stable overexpression of human arresten (arrHSC-3) is described in Aikio et al. [19]. HEK-293 cells grown under the selective pressure of Geneticin G418 antibiotic were used to purify recombinant human arresten in an anti-flag affinity column as described previously [19]. All cells were cultured in a humidified atmosphere of $5 \% \mathrm{CO}_{2}$ at $37^{\circ} \mathrm{C}$ and passaged routinely using trypsin-EDTA (Sigma-Aldrich). Mycoplasma infection was excluded by regular testing with MycoTrace PCR Detection Kit (PAA Laboratories $\mathrm{GmbH}$ ).

\subsection{RNA extraction and PCR}

Total RNA was extracted from subconfluent shMMP9 and control HSC-3 cells with TRI Reagent (Sigma-Aldrich) according to the manufacturer's instructions. cDNA was synthesized with SuperScript ${ }^{\circledR}$ III First-Strand Synthesis System (Life Technologies) and semi-quantitative PCR reactions were conducted with AmpliTaq Gold ${ }^{\circledR}$ DNA Polymerase (Life Technologies) using MMP9 forward primer 5'-CACTGTCCACCCC TCAGAGC- $3^{\prime}$ and reverse primer $5^{\prime}$-GCCACTTGTCGGCGATAAGG-3' as described earlier [20]. As a control of the RNA amount, $\beta$-actin was measured from the same cDNA samples using forward primer $5^{\prime}$-AAC TGGGACGACATGGAGAAAA-3' and reverse primer $5^{\prime}$-AGAGGCGTACA GGGATAGCACA- $3^{\prime}$. The annealing temperature was $64^{\circ} \mathrm{C}$ for MMP9 and $54^{\circ} \mathrm{C}$ for $\beta$-actin.

\subsection{Zymography}

Subconfluent cultures of HaCaT, HGF, IHGK, SCC-25 and HSC-3 (control and shMMP9) and MDA-MB-231 cells were cultured in OptiMEM (Gibco) and control and arrHSC-3 in 1\% lactalbumin (SigmaAldrich) medium for $24 \mathrm{~h}$ and media were collected for zymography. In some cases, the cell layers were scratched by pipette tip and media were collected after $24 \mathrm{~h}$ and $48 \mathrm{~h}$ with their unscratched controls. Zymography was performed as previously described [21] using either the same media protein amount or sample volume. The cells were lysed for zymography as described in the 'Western blot' section.

\subsection{Myoma organotypic cultures and immunohistochemistry}

Myoma organotypic cultures were prepared as previously described $[22,23]$. Briefly, uterine leiomyoma tissue was obtained during routine surgeries with the informed consent of the donors. The study protocol was approved by the Regional Ethics Committee of the Northern Ostrobothnia Hospital District (statement number 35/2014). The myoma discs were cut with an $8 \mathrm{~mm}$ biopsy punch. In some experiments, myomas were rinsed in cell culture medium at $4{ }^{\circ} \mathrm{C}$ for 10 days prior to cell culturing to remove soluble factors [24]. The rinsing medium was changed twice a week. Myoma discs were placed into Transwell ${ }^{\circledR}$ inserts (diameter $6.5 \mathrm{~mm}$; Corning) and $3 \times 10^{5}$ or $7 \times 10^{5} \mathrm{HSC}-3$ cells in $50 \mu \mathrm{l}$ of medium were added on the top of the myoma disc. The next day, the discs were transferred onto uncoated nylon membrane (Prinsal Oy) resting on curved steel grids in 12-well plates with $1 \mathrm{ml}$ of medium. Cells were cultured on the top of the myoma disc for 10-14 days. In some experiments, $100 \mu \mathrm{M}$ CTT2-peptide GRENYHGCTTHWGFTLC [15] and its scrambled control peptide LEHGTFCGRYTGCWNHT (both from Polypeptide group) or $100 \mathrm{nM}$ or $500 \mathrm{nM}$ recombinant arresten was added before the discs were placed into Transwell ${ }^{\circledR}$ inserts.

The tissues were fixed in $4 \%$ neutral-buffered formalin overnight, dehydrated and embedded in paraffin. Then $6-\mu \mathrm{m}$ sections were deparaffinized and endogenous peroxidase was blocked with $\mathrm{H}_{2} \mathrm{O}_{2}$ in methanol as the specimens were prepared for immunohistochemistry with monoclonal pan-cytokeratin AE1/AE3 antibody (Dako) to identify carcinoma cells, and invasion was quantified as described earlier $[22,23]$. Briefly, histological sections were photographed with a DMRB photo microscope connected to a DFC-480 camera using QWin V3 software (Leica Microsystems) or with an Olympus BX61 light-field microscope equipped with an Olympus U-CMAB3 camera. The invasion depth and areas of non-invading and invading cells were measured with QWin V3 software, and the invasion index was calculated as previously described $[22,23]$. 


\subsection{Transwell ${ }^{\circledast}$ migration assay}

Transwell ${ }^{\circledast}$ membrane inserts with $8 \mu \mathrm{m}$ pores (Corning) were equilibrated with $600 \mu \mathrm{l}$ of cell culture medium for $1 \mathrm{~h}$ before adding the cells. Then $7 \times 10^{4}$ shMMP9, arresten-overexpressing, corresponding control or parental HSC-3, SAS, SCC-25 or MDA-MB-231 cells were seeded into the upper chamber of Transwell ${ }^{\circledR}$ inserts in medium containing $0.5 \%$ lactalbumin. CTT2 was added to the upper chamber in serum-free medium after the cells had attached for $3 \mathrm{~h}$. The medium in the lower chamber contained $10 \%$ FBS. After $24 \mathrm{~h}$ or $48 \mathrm{~h}$, the cells were fixed with $10 \%$ trichloroacetic acid (TCA) for $15 \mathrm{~min}$, washed three times with $\mathrm{dH}_{2} \mathrm{O}$, allowed to dry and stained with $0.1 \%$ crystal violet. Cells from the upper side of the membrane were removed by using a cotton swab. Membranes were detached from the inserts by using a scalpel, attached to glass slides and photographed with a microscope using Leica Application Suite (LAS) software (Leica Microsystems). The area of cells and total membrane area were measured using QWin V3 software (Leica Microsystems), and the percentage of cell area was calculated. Alternatively, the cells were fixed and stained with Toluidine Blue. After removing the cells and excess dye from the upper side of the membrane, the dye of migrated cells was eluted with $1 \%$ SDS and the absorbance was measured at $650 \mathrm{~nm}$ using a Victor2 Microplate Reader (Perkin Elmer Wallac) [25].

\subsection{Scratch wound healing assays}

In these assays, $2.5 \times 10^{5}$ shMMP9 or control HSC-3 cells were allowed to attach overnight in 24-well plates. The cell cultures were scratched with $1 \mathrm{ml}$ pipette tip, and the wells were rinsed with serumfree medium before adding medium with $1 \%$ FBS. The cells were photographed with an EVOS photo microscope. In some cases, 24-well plates were coated with $70 \mu \mathrm{g} / \mathrm{ml}$ rat tail type I collagen (BD Biosciences), $10 \mu \mathrm{g} / \mathrm{ml}$ fibronectin (Sigma-Aldrich) and $0.62 \mathrm{mg} / \mathrm{ml}$ Matrigel ${ }^{\circledR}$ (BD Biosciences) for $2 \mathrm{~h}$ in $37^{\circ} \mathrm{C}$ and washed twice with PBS. Next, $9 \times 10^{4}$ shMMP9 or control HSC-3 cells were allowed to attach overnight before wounding with the pipette tip, rinsed twice with PBS, re-coated for $1 \mathrm{~h}$ and washed. The open area between the two cell edges was measured with QWin V3 or Fiji software [26]. The results were calculated as a percentage of the original empty area $(0 \mathrm{~h})$.

\subsection{Cell proliferation assay}

Cell proliferation was measured with Cell Proliferation ELISA, BrdU (colorimetric) kit (Roche Diagnostics) according to the manufacturer's instructions. Next, $1 \times 10^{4}$ control, shMMP9 or arrHSC-3 HSC-3 cells were allowed to attach in 96-well plates overnight, 24 or $48 \mathrm{~h}$ before adding $10 \mu \mathrm{l} \mathrm{BrdU-labelling} \mathrm{reagent.} \mathrm{The} \mathrm{incorporation} \mathrm{of} \mathrm{5-bromo-2'-}$ deoxyuridine (BrdU) into newly synthesized DNA of proliferating cells was measured by absorbance at $450 \mathrm{~nm}$ using a Victor2 Microplate Reader (Perkin Elmer Wallac).

\subsection{Microarray}

shMMP9 and control HSC-3 cells were cultured in triplicate in 6well plates. The next day, the cells were scratched with a $1 \mathrm{ml}$ pipette tip at $\sim 2.5 \mathrm{~mm}$ intervals horizontally and vertically (migratory phenotype); three wells were left unwounded (stationary phenotype). Medium with $1 \%$ FBS was added after $10 \mathrm{~h}$ and the total RNA was extracted using RNEasy Mini Kit (Qiagen) according to the manufacturer's instructions. Microarray was performed and analysed by Affymetrix GeneChip Human Genome U133 Plus 2.0 according to the Affymetrix GeneChip Expression Analysis Technical Manual's instructions using $1 \mu \mathrm{g}$ of total RNA as template (described in detail previously [12]). The arrays were scanned on a GeneChip Scanner 3000 and DAVID 6.7 was used for Gene Ontology analyses [27].

\subsection{Western blot}

Equal number of cells were lysed in $50 \mathrm{mM}$ Tris- $\mathrm{HCl} \mathrm{pH} \mathrm{7.5,} 10 \mathrm{mM}$ $\mathrm{CaCl}_{2}, 150 \mathrm{mM} \mathrm{NaCl}, 0.05 \%$ (v/v) Brij-35 (Sigma-Aldrich) buffer including Complete mini EDTA-free protease inhibitor cocktail (Roche). The cell debris was removed by centrifugation. The protein concentrations were measured with DC Protein assay (Bio-Rad) and $20 \mu \mathrm{g}$ of soluble proteins were separated under reducing conditions by $12 \%$ SDS-PAGE gels and transferred to an Immobilon-P membrane (Millipore). The membranes were blocked with $5 \%$ milk powder or $5 \%$ BSA (for Phospho-antibodies) in Tris-buffered saline $0.1 \%$ Tween 20 and incubated overnight with p44/42 MAPK (Erk1/2), Phospho-p44/ 42 MAPK (Erk1/2) (Thr202/Tyr204), Akt, Phospho-Akt (Ser473) (1:1000, all from Cell Signaling Technology), fibronectin (1:1000, ab24139) or beta Actin (1:2000) (both from Abcam) antibodies followed by biotinylated secondary antibodies (1:5000, DAKO) and Vectastain ABC kit (Vector Laboratories). Immunocomplexes were visualized using a Pierce ECL Western blotting substrate (Thermo Scientific) and a Luminescent image analyzer LAS-3000 (Fujifilm).

\subsection{Statistical analysis}

All assays were repeated 2-4 times. Each myoma experiment was performed with triplicate myoma discs per culture condition. Differences in cell proliferation, Transwell ${ }^{\circledR}$ migration, scratch wound healing, invasion area, depth and index were evaluated by using Student's $t$-test in the IBM SPSS Statistics version 20 software. In all experiments, a $p$-value of less than 0.05 was considered significant.

\section{Results}

3.1. MMP9 is expressed in benign and malignant cell lines and its amount increases during cell migration

We first confirmed the expression of MMP9 in various cell lines and further observed its expression during cell migration. ProMMP9 was detected in the medium of all oral cell lines of epithelial origin examined (HGF, IHGK, SCC-25 and HSC-3) (Fig. S1A), but the molecular weight corresponding to the active form of MMP9 was not detected. Pro-form of MMP2 was expressed by all of the cell lines and the active form was also detected in most of the cell lines examined. The expression of proMMP9 was strongly increased by scratching the HSC-3 cell layer after $24 \mathrm{~h}$ (Fig. 1A). The proMMP9 expression in HSC-3 cells was further increased after $48 \mathrm{~h}$, but at this time point the wounding no longer induced the expression. Furthermore, no activation of proMMP9 or proMMP2 was detected upon wounding. Similar (but lower) increase of MMP9 expression was also detected in the migrating breast carcinoma cell line MDA-MB-231 (Fig. S1B).

\subsection{Gelatinase inhibitor peptide CTT2 increases the motility of HSC-3 cells}

Because MMP9 expression was increased in migrating cells, we next examined the effect of MMP9 inhibition on cell migration and invasion. Gelatinase inhibitor CTT2 - a synthetic cyclic peptide

that specifically inhibits the activity of gelatinases $[13,15]$ - was applied to the three different OTSCC and MDA-MB-231 cell lines in Transwell ${ }^{\circledR}$ chambers after attachment (Fig. 1B and S1C-E). As expected based on previous in vitro findings on breast cancer cells [28-30], CTT2 inhibited the migration of MDA-MB-231 cells $(48 \mathrm{~h}, \mathrm{p}<0.05$, Fig. S1C). Of the three different OTSCC cell lines examined, CTT2 inhibited the migration of SAS cells ( $24 \mathrm{~h}$ and $48 \mathrm{~h}, \mathrm{p}<0.05$, Fig. S1D), had no effect on SCC-25 cells (Fig. S1E) and slightly increased the migration of HSC-3 cells ( $p=0.057$, Fig. 1B). After $48 \mathrm{~h}$, the difference in migration of HSC-3 cells disappeared. In the myoma organotypic culture, the tumour cells treated with CTT2 invaded significantly deeper than the control cells ( $p<0.001$, Fig. 1C-D). The invasion index was also 
A

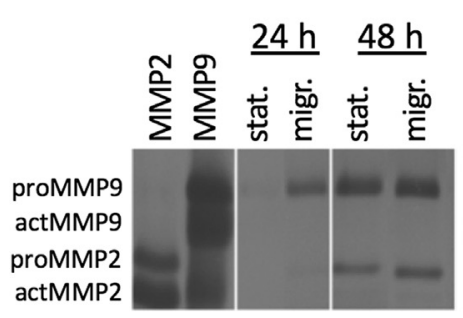

B

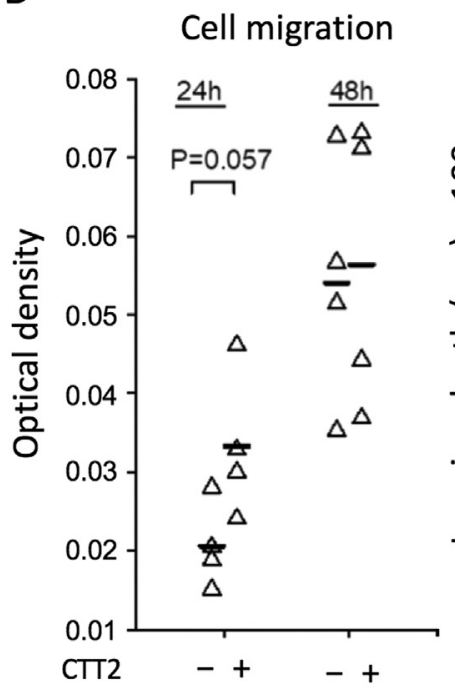

C

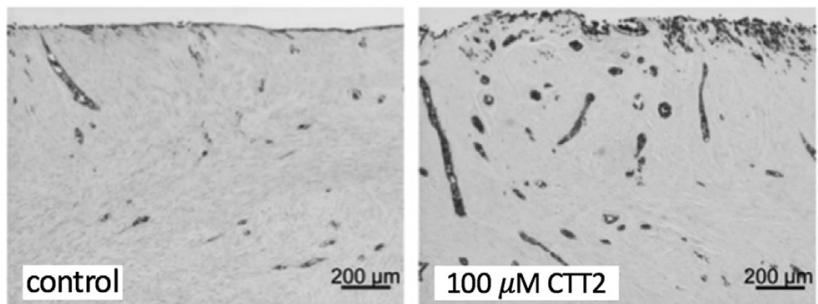

Fig. 1. (A) HSC-3 cell cultures were wounded, and media were collected with their unwounded controls at $24 \mathrm{~h}$ and $48 \mathrm{~h}$. The level of MMP9 was analysed from equal amounts of cell culture media by zymography. Purified gelatinase standards are shown on the left: pro-MMP9 (92 kDa), active MMP9 (82 kDa), pro-MMP2 (72 kDa) and active MMP2 (62 kDa). (B) Migration of HSC-3 cells was analysed with Transwell ${ }^{\circledR}$ assay in serum-free medium or in medium containing CTT2. The cells were fixed and stained with Toluidine Blue after $24 \mathrm{~h}$ or $48 \mathrm{~h}$. The dye was eluted in SDS and the absorbance at $650 \mathrm{~nm}$ was measured. $\mathrm{N}=4$ wells per experimental condition. (C) Invasion of control and $100 \mu \mathrm{M}$ CTT2treated HSC-3 cells was analysed with myoma organotypic cultures after 10 days. The invasion depth (D) and invasion index (E) of HSC-3 cells were analysed from pan-cytokeratin stained myoma sections (three or four myoma discs per culture condition, each with 16-48 sections) using Fiji software. Pvalues were calculated using Student's T-test. * $\mathrm{p}<0.05$, ** $\mathrm{p}<0.01$, *** $\mathrm{p}<0.001$.

significantly higher in CTT2-treated cells than in controls $(\mathrm{p}<0.01$, Fig. 1E).

\subsection{Silencing of MMP9 increases the migration and invasion of HSC-3 cells}

To get further confirmation for the observed influence of MMP9 on oral carcinoma cell migration, and because CCT2 also inhibits MMP2 activity, MMP9 was silenced in HSC-3 and SAS cells (which had the opposite effect on CTT2 inhibition) using lentivirus-mediated RNA interference (shMMP9). The efficiency of MMP9 silencing in stable transduced cell lines was determined by semi-quantitative PCR and zymography. However, in SAS cells the inhibition of MMP9 was not successful (not shown), and therefore, we focused our studies only on HSC- 3 cells. In HSC-3 cell culture medium, the protein level of MMP9 was decreased by $30-70 \%$ (comparison of band intensities in zymography) in silenced cells relative to control cells transduced with scrambled lentivirus (Fig. 2B). The diminished level of MMP9 mRNA in cells was also detected by PCR (Fig. 2A). Zymography showed that silencing of MMP9 in HSC-3 cells did not change the level of MMP2 (Fig. S2A). In addition, MMP9 and MMP2 were only detected in the medium and not in the cell extracts (Fig. S2A). shMMP9-1 (representing a higher degree of silencing) and/or -3 (representing a lower degree of silencing) were used in subsequent experiments. Both shMMP9 clones showed significantly less cell proliferation than control cells $(\mathrm{p}<0.001$, Fig. S2B). In line with CTT2 inhibition, shMMP9 cells migrated significantly faster than control cells in the scratch wound assay ( $p<0.001$, Fig. 2C, 24h) and in the Transwell ${ }^{\oplus}$ migration assay ( $<<0.001$, Fig. 2D, $24 \mathrm{~h}$ and $48 \mathrm{~h}$ ). Likewise, the invasion area of shMMP9 cells was slightly increased in myoma organotypic culture $(p<0.05$, Fig. 3A-B). However, in myoma tissue there was no difference in invasion depth between shMMP9-1 or -3 cells and control cells (Fig. 3C). Altogether our migration and invasion assays suggested that MMP9 inhibits motility of HSC-3 cells in vitro.

3.4. Fibronectin expression and activation of Akt pathway is upregulated in shMMP9 HSC-3 cells

To better understand the overall effects of MMP9 silencing on the cells, we examined the gene expression profiles of shMMP9 cells compared with controls in stationary and migrating phenotypes. In silenced cells, MMP9 expression was confirmed to be downregulated. In stationary cells, approximately 366 genes reached the FC $>1.5$ difference in expressions (Supplementary Table 2), whereas in migrating cells the number of changed genes was 262 (Supplementary Table 3) (GEO) between the shMMP9 and control cells. The genes were annotated to functional groups with the DAVID annotation tool [27]. The most significant changes between shMMP9 cells and controls were observed in genes annotating to the GO-terms "Regulation of cell proliferation" and "Response to wounding" in stationary cells (Supplementary Table 4) and to "Extracellular region part" and "Response to Wounding" in migrating cells (Supplementary Table 5). Among the upregulated genes in stationary cells, we found fibronectin, a matrix glycoprotein associated with various phases of tumorigenesis [31]. The increased amount of fibronectin was also observed at the protein level (Fig. 4A).

To examine the effect of fibronectin on the migration of shMMP9, we performed a scratch assay on top of various coatings, including fibronectin. Interestingly, of the three different substrates, fibronectin was the only one that slightly increased the migration of shMMP9 cells already at $8 \mathrm{~h}$ compared with control cells $(\mathrm{P}=0.057$, Fig. 4B). Type I collagen and Matrigel did not have a similar effect at this time point ( $8 \mathrm{~h}$, Fig. S3). After $24 \mathrm{~h}$, the migration of shMMP9 cells was slightly increased compared with control cells on all coatings used, but the increase was significant only when non-coated wells were used ( $\mathrm{P}=0.029,24$ h, Fig. S3). 

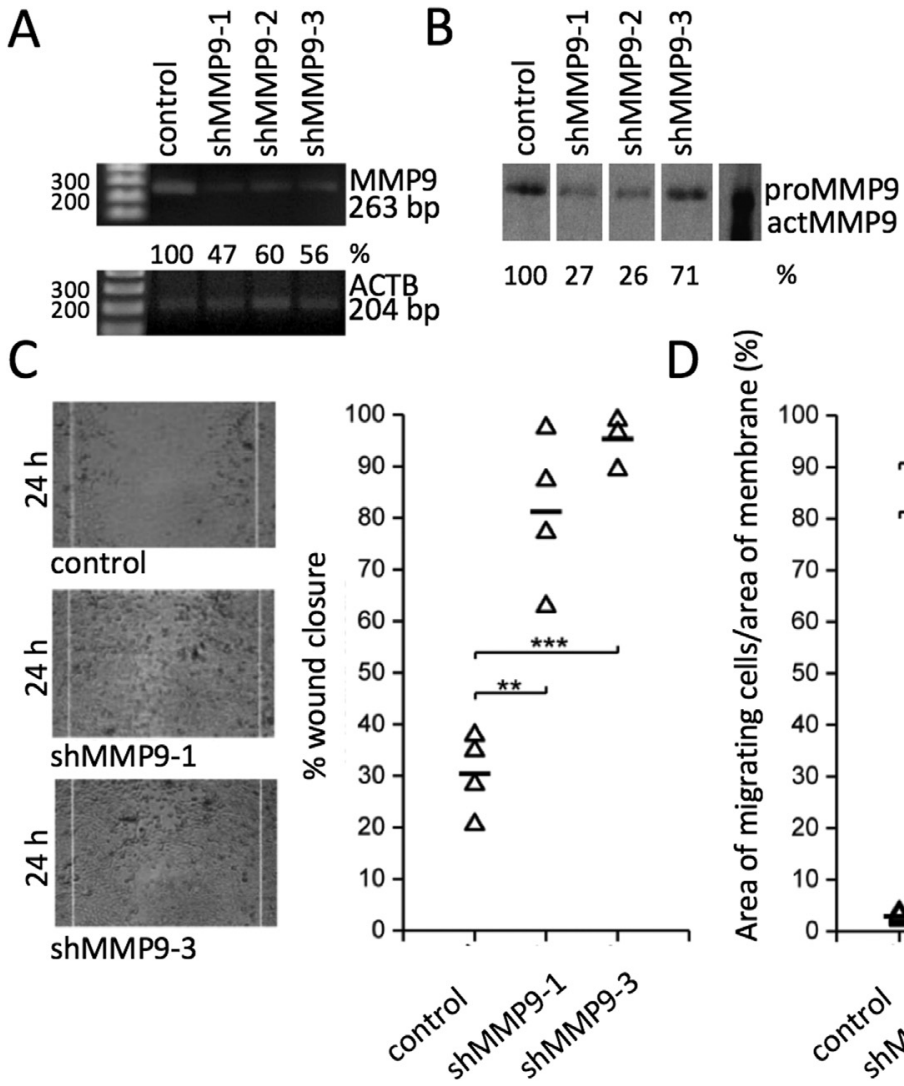
actMMPg
$\%$

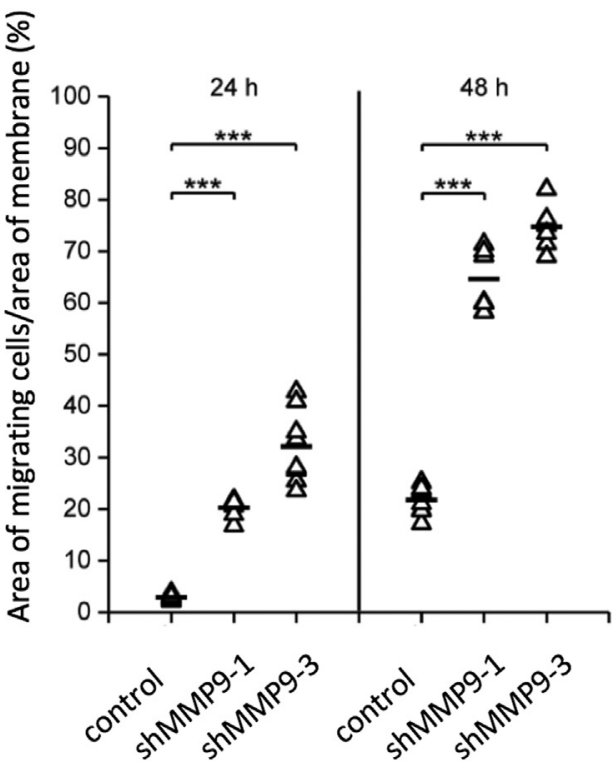

Fig. 2. MMP9 silencing in HSC-3 cells stable transduced with three different MMP9 lentiviral shRNAmir particles (shMMP9-1, -2 and 3) was verified by (A) PCR and (B) zymography. $\beta$-actin (ACTB) was used to control the RNA amount. The values represent the quantitation of the band intensities compared with control. Zymography was performed using equal amounts of culture media. Scrambled shRNAmir particles transduced HSC-3 cells were used as a control (control HSC-3 cells) in experiments. Purified gelatinase standards are shown on the right: proMMP9 (92 kDa) and active MMP9 $(82 \mathrm{kDa})$. For further experiments, shMMP9 cell lines -1 and -3 were used. (C) Migration of the control and shMMP9 HSC-3 cells was analysed with a scratch wound assay. The wounds were photographed with EVOS photo microscope after $24 \mathrm{~h}$ and the area of open wound was measured as described in methods. White stripes in the wound photographs represent the edges of the wound at time point $0 \mathrm{~h}$. Results are the mean of 4 samples. (D) Migration of shMMP9 cells (shMMP9-1 and -3) was analysed with Transwell ${ }^{\circledast}$ assay in serum-free medium. The cells on the underside of membranes were stained with crystal violet after $24 \mathrm{~h}$ or

$48 \mathrm{~h}$, photographed and the area of migrated cells was measured using QWin V3 software. Results represent the mean of 6 samples. P-values were calculated using Student's T-test. ${ }^{*} \mathrm{p}<0.05,{ }^{* *} \mathrm{p}<0.01,{ }^{* * *} \mathrm{p}<0.001$.

Fibronectin affects tumour progress by activating ERK1/2 and Akt/ PI3K pathways [31]. Western blot analysis revealed that MMP9 silencing also increased the phosphorylation of Akt (protein kinase B; PKB), but it had no effect on total or phosphorylated Erk1/2 (Fig. S4A). Of note, MMP9 dimers, known to participate in MMP9-induced cell migration [32], were not detected in any of the cell lines examined (Fig. S4B).

\subsection{MMP9 is involved in mediating the tumour-suppressive effects of arresten}

ArrHSC-3 cells with reduced migration [19] showed increased expression of MMP9 (but slightly reduced expression of MMP2) (Fig. 5A and C). To examine whether the increased MMP9 level is of significance in the decreased invasion in this cell line, we inhibited MMP9 by CTT2. In control cells, CTT2 again slightly increased the cell migration after $24 \mathrm{~h}(\mathrm{P}=0.057,24 \mathrm{~h}$, Fig. 5B). After $48 \mathrm{~h}$, CTT2 increased the migration of arrHSC-3 cells to the level of control cells ( $48 \mathrm{~h}$, Fig. 5B). Also, in these cells, MMP9 levels were increased due to the migration and after longer incubation (Fig. 5C). We confirmed the previously shown effect of arresten on cell motility [19] in various 3D invasion models. We utilized human myoma tissue discs equilibrated with medium containing arresten to confirm the earlier findings [19] showing the antimigratory effect of arresten. We found cell invasion to be almost completely prevented by $500 \mathrm{nM}$ arresten (Fig. S5A-D). Arresten $100 \mathrm{nM}$ was not sufficient to reduce the invasion. The inhibiting effect on invasion was also observed in arrHSC- 3 cells, where the invasion depth and the area were significantly lower than in control cells in myoma organotypic culture ( $<<0.05$ and $\mathrm{p}<0.01$, respectively, Fig. S6A-D). Moreover, overexpressed arresten significantly increased the proliferation of HSC-3 cells after $48 \mathrm{~h}$ (Fig. S2C, p < 0.001), which was opposite to what we observed for shMMP9 cells.

\section{Discussion}

The role of MMP9 in oral carcinoma has been studied extensively in human cancers, yielding partly contradictory results. Moreover, mouse experiments have not been able to demonstrate that inhibiting gelatinases decreases the invasive spread of oral cancer [14], although in some cases it decreases [13] or even increases primary tumour growth [14] depending on the inhibitor(s) used. Despite the highly conflicting and indefinite in vivo evidence on the function of MMP9 in oral cancer, there are only a few studies evaluating its effects on oral carcinoma cells in vitro. Hence, in this study, we focused on examining the role of MMP9 in invasion and migration of oral carcinoma cell lines in vitro using various technical approaches. Interestingly, we found that although migrating cells increase their MMP9 expression, it may not be driving, but rather inhibiting, the migration process. We demonstrated the inhibitory effect of MMP9 on cell motility first by using a specific inhibitor of MMP2 and - 9 activities, the CTT2 peptide, and confirmed the results by shRNA silencing of MMP9 expression. CTT2 is a synthetic cyclic peptide, selected from libraries of random peptides shown to specifically bind and inhibit the activity of gelatinases (MMP2 and -9) without affecting their mRNA expression levels [13,15]. Interestingly, mice with HSC-3 xenograft tumours treated with CTT2 had smaller primary tumours than the control group [13]. In line with this, we found that MMP9 inhibits proliferation of HSC-3 cells in vitro. However, another gelatinase inhibitor CTT1 did not inhibit metastasis formation [14] in the mouse. Using a combination of gelatinase inhibitors in mouse OTSCC xenograft model, the tumour size was increased compared with the sole CTT therapy [14]. This clearly demonstrates that inhibiting gelatinase activities does not have only antitumoral effects in vivo, as one might expect based on immunohistochemical analyses of MMP9 expression in human OSCC tissues [4].

We found that CTT2 had different effects on the vertical migration 


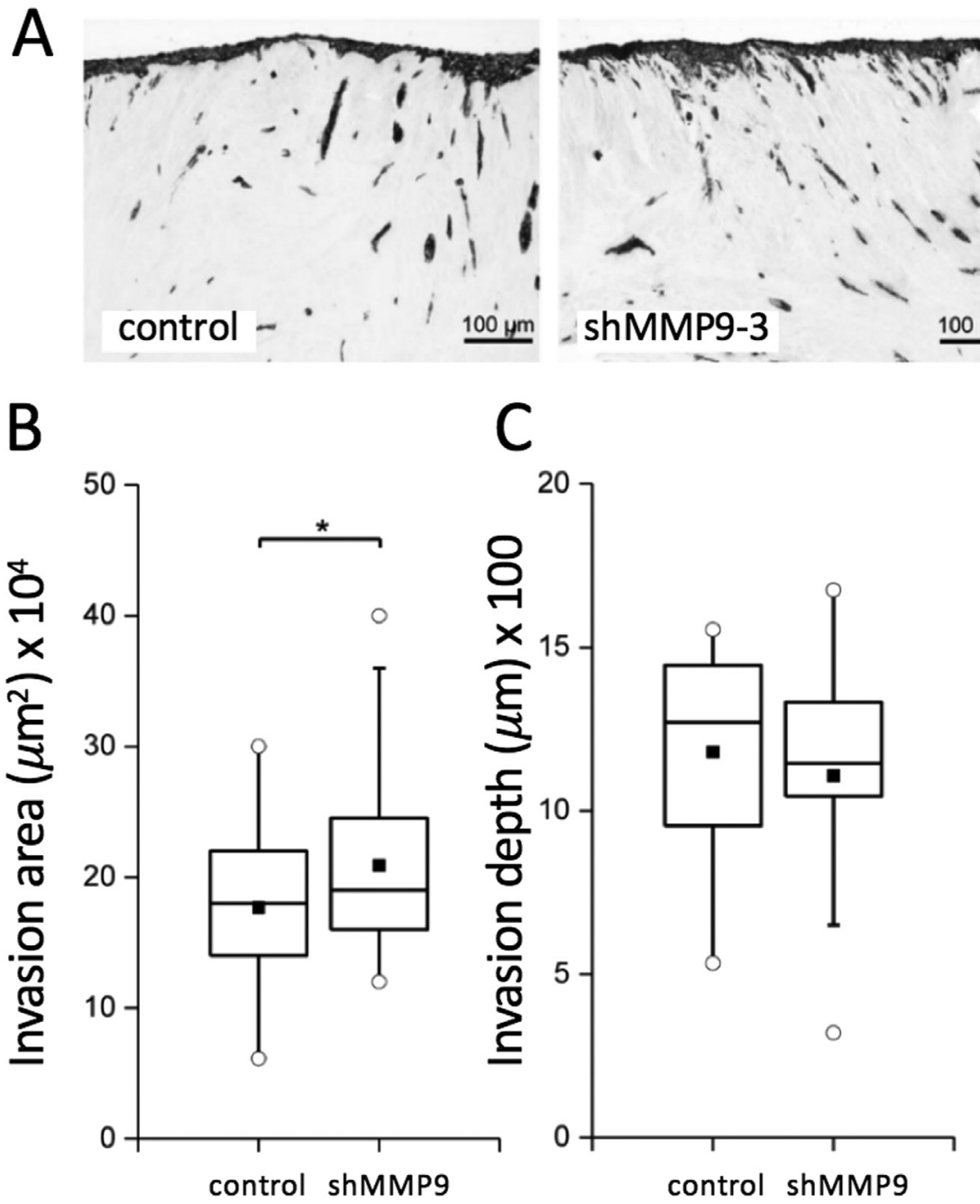

Fig. 3. (A) Invasion of control and shMMP9 HSC-3 cells was analysed using myoma organotypic cultures and the invasion area and depth were measured from pancytokeratin stained sections (B-C). In myoma experiments, $3 \times 10^{5}$ shMMP9 or control HSC-3 cells were cultured for 10 days on top of the myoma discs. Myoma experiments were performed once with three or four myoma discs per culture condition, 16-48 pan-cytokeratin stained sections per condition were analysed using Fiji software. P-values were calculated using Student's T-test. ${ }^{*} \mathrm{p}<0.05,{ }^{* *} \mathrm{p}<0.01,{ }^{* * *} \mathrm{p}<0.001$.

of various OTSCC cell lines: it had no effect on SCC-25, inhibited SAS, but increased the migration of the most aggressive and highly metastatic HSC-3 cell line [33,34]. Thus, our data suggest that mechanisms of MMP9 depend on the various genetic and cellular properties of OTSCC cells. In earlier studies, CTT2 was shown to inhibit the migration of HSC-3 cells $[13,35]$. However, in those experiments, CTT2 was applied to the cells prior to their plating, unlike in our experiments, where the inhibitor was added after the cells were attached to the wells. These experimental differences most likely caused the discrepancies in cell migration results since we were able to confirm the inhibitory effect of CTT2 on HSC-3 $48 \mathrm{~h}$ migration by allowing the cells to attach in the presence of CTT2 (data not shown), as previously described. Likewise, CTT2 increased the invasion of HSC-3 cells in human myoma organotypic culture, in which the effect of CTT2 on migration was more drastic than in the Transwell migration assay. This might be due to anti-proliferative effects of MMP9 inhibition that most likely affects less in the myoma model. In myoma, cells keep their migratory (rather than proliferative) phenotype longer that in Transwells, where they reach the membrane and might thereafter adapt the proliferative phenotype. HSC-3 cells expressed more MMP9 than MMP2, so the inducing effect of CTT2 on the invasion of HSC-3 cells is likely due to MMP9 inhibition. This was confirmed by shRNA silencing of MMP9, which significantly induced the migration of HSC-3 cells, as we showed by various experimental models. The decreased proliferation of MMP9-silenced HSC-
3 cells (shMMP9) could also be a result of an increased migratory phenotype. The finding that MMP9 silencing can in certain conditions decrease the cell proliferation may also explain the previous results that CTT2 inhibits tumour growth in a mouse model [13].

We have previously shown that HSC-3 cells invading myoma together with M1 macrophages have a higher level of MMP9 than in the presence of M2 macrophages [36]. Importantly, M2 macrophage is the phenotype displayed by most tumour-associated macrophages able to induce cancer growth [36]. We have also demonstrated that MMP8overexpressing HSC-3 cells, with significantly decreased cell invasion and migration, have increased MMP9 expression [12]. Here, we further showed that arrHSC- 3 cells, also revealed to have reduced motility [19], had elevated MMP9 expression levels and a concomitant reduction in the amount of MMP2. In these cells, inhibiting MMP9 activity by gelatinase inhibitor CTT2 (which inhibits both MMP9 and MMP2) restored their migration. This demonstrates that the decreased migration capacity of arresten-overexpressing cells was partly due to increased MMP9 expression. These findings further suggest the important inhibitory role of MMP9 in cell invasion and migration of an aggressive HSC-3 cell line.

Fibronectin, one of the upregulated genes in shMMP9 HSC-3 cells, is connected to the pathogenesis of OTSCC $[37,38]$, and it regulates and activates MMP9 in breast and laryngeal cancers [39,40]. Fibronectin affects tumour progression by altering MMP expression and activating 
A

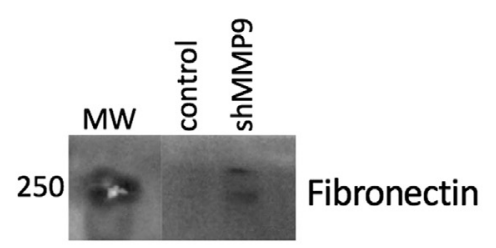

B

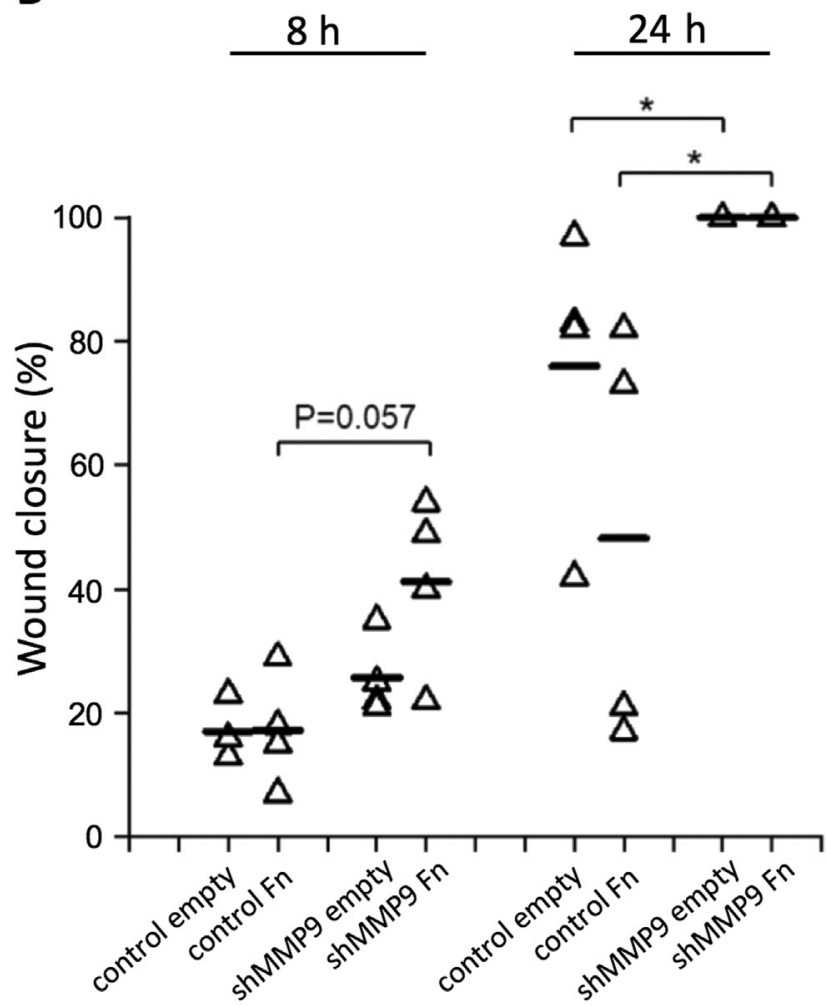

Fig. 4. (A) The amount of fibronectin in the control and shMMP9 HSC-3 cell homogenates ( $20 \mu \mathrm{g}$ of soluble protein) was analysed with Western blotting. (B) Migration of the shMMP9 and control HSC-3 cells was analysed with a scratch wound assay on uncoated (empty) and $10 \mu \mathrm{g} / \mathrm{ml}$ fibronectin (Fn)-coated size 24 wells. The wounds were photographed with an EVOS photo microscope at $8 \mathrm{~h}$ and $24 \mathrm{~h}$ after scratching. The area of the open wound was measured with Fiji software and the results are presented as a percentage of wound closure $(n=4$ scratch wounds analysed per condition). P-values were calculated using Student's T-test. ${ }^{*} \mathrm{p}<0.05,{ }^{* *} \mathrm{p}<0.01,{ }^{* * *} \mathrm{p}<0.001$.

ERK1/2 and Akt/PI3K pathways via FAK phosphorylation and Src recruitment [31]. It promotes in vitro invasion and migration of A549 lung cancer cells [31] and activates the PI3K/Akt pathway in hepatocellular carcinoma [41]. Fibronectin itself is induced through the PI3K/ Akt pathway in human retinal pigmental epithelial cells [42]. Concomitantly, phosphorylation of Akt was increased in our MMP9-silenced HSC-3 cells. The Akt pathway regulates the expression of a range of proteins involved in the modulation of cell proliferation and growth [43] and is one of the downstream effectors of the EGFR signalling pathway. The activation of PI3K/Akt signalling, a tumour-promoting pathway, may reflect or be a result of the increased aggressiveness of shMMP9 cells. Activation of PI3K/Akt signalling has been linked to shorter disease-free survival and worse outcome also in OTSCC $[44,45]$. The finding that shMMP9 cells migrated slightly faster on fibronectin coating than control cells might be a result of their improved response to extracellular fibronectin due to their increased exogenous fibronectin expression. Interestingly, MMP9 dimers, which have been shown to be essential for MMP9-enhanced cell migration in MD-MBA-435 breast cancer cells [32], were not detected in any of the cell lines here. The activation of MMP9 is also affected by the capability of proMMP9 to form dimers, such as hetero- or homodimers, through its C-terminal hemopexin (HPX) domain [46]. It is possible, though, that in our experimental settings homodimers are formed very locally, and thus, are not detected by zymography.

MMP9 is a difficult target for anticancer drug development, mainly because of its both pro- and anti-tumorigenic effects [47]. A metaanalysis found that MMP9 overexpression is a predictor of poor prognosis in OTSCC patients [4]. However, its effect on tumour progression in OTSCC is unclear. Although there are publications showing a protumorigenic role for MMP9 in cancer progression [48,49], most studies support our findings. Stokes et al. showed that MMP9 mRNA in primary tumours was significantly decreased in those head and neck squamous cell carcinomas with metastasis compared with non-metastatic tumours [8]. Moreover, there is evidence from other cancer types supporting the protective role of MMP9. Vaccinia virus-mediated gene transfer of MMP9 regressed prostate cancer growth [50], and MMP9 gene transfer by adenovirus dose-dependently decreased tumour growth in breast cancer [51]. MMP9 has previously been reported to have anti-tumorigenic effects also on skin and colon cancer via its involvement in invasion and angiogenesis [52]. In addition, MMP9 deficiency resulted in skin tumours with higher malignant grades in K14-HPV16 transgenic mice [53]. There are also studies based on patient data where a correlation between MMP9 expression and poor prognosis in OTSCC has not been found [54] and where MMP9 expression showed a tendency (i.e. not significant) for better prognosis [55]. Because of the discrepancy between in vivo and in vitro findings, results gained solely with tumour cells, such as ours here, should be viewed critically. The complexity of TME is, after all, beyond any in vitro models, as they lack the elements that angiogenesis affects (vascularity) as well as inflammatory cells and other possible proteins or co-factors that may be involved in the pathways of enzyme activity. However, we wanted to mimic the TME in our in vitro experiments, and hence, also used our human myoma-derived organotypic model to more reliably evaluate the effects of MMP9 on cell behaviour [22,23]. Because of the diversity of the effects and functions of MMP9 reported in vitro, it would be highly important to evaluate whether the upregulated MMP9 in vivo has a true pathogenic effect or whether the upregulation is actually caused by the disease. The upregulation of MMP9 may also be a protective response of the host against the tumour [47], as in the case of MMP8 [12,55]. MMPs in vivo may play both pro- and antitumorigenic roles, depending on the nature of the cancer.

\section{Conclusions}

Our study provides strong evidence for the inhibiting effects of MMP9 on motility of HSC-3 cells, an oral tongue carcinoma cell line with a high metastatic potential. However, based on our experiments with CTT2 inhibitor, other OTSCC cell lines responded differently to the changes in MMP9 levels, suggesting that mechanisms of MMP9 depend on the various genetic and cellular properties of the cell lines. Although high MMP9 expression is usually linked to poor prognosis of OTSCC patients, our study suggests that it might not solely drive tumour progression, but may also have anti-migratory, yet unidentified, effects on OTSCC. More in vivo studies are needed to reveal the function of MMP9 in different stages of OTSCC progression.

\section{Acknowledgements}

Work with lentiviral particles was done at the Biocenter Oulu Virus Core laboratory. Eeva-Maija Kiljander, Maija-Leena Lehtonen, Sanna Juntunen, Merja Tyynismaa, Maritta Harjapää and Tanja Sarajärvi are thanked for skilful technical assistance. Ahmed Al-Samadi and Sirpa Salo are acknowledged for insightful comments on the manuscript. We thank Assistant Professor Antoine Dufour for valuable suggestions on this research and for reviewing the manuscript. This study was financially supported by the Academy of Finland, the Cancer Foundation of 
A

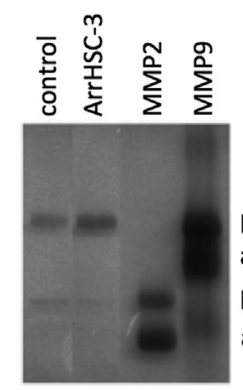

proMMPg

actMMP9

proMMP2

actMMP2
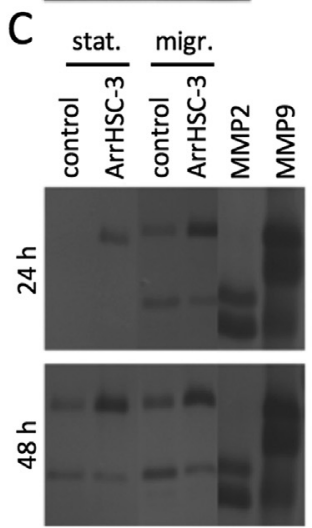

proMMPg

actMMPg proMMP2 actMMP2

proMMPg actMMPg proMMP2 actMMP2
B

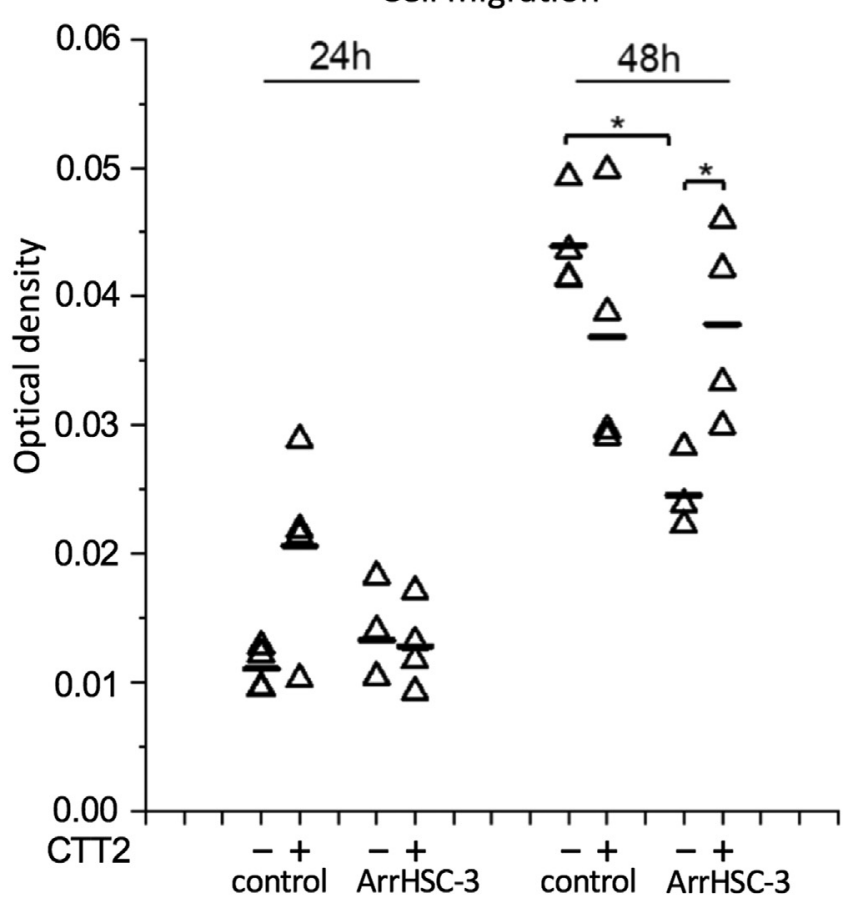

Fig. 5. (A) Conditioned media of arresten-overexpressing HSC-3 cells and their controls were analysed with zymography after $48 \mathrm{~h}$ as described in methods. (B) Migration of control and arrHSC-3 cells was analysed with Transwell ${ }^{\circledR}$ assay in serum-free medium or in medium containing CTT2. The cells were fixed and stained with Toluidine Blue after $24 \mathrm{~h}$ or $48 \mathrm{~h}$. The dye was eluted in SDS and the absorbance at $650 \mathrm{~nm}$ was measured. $\mathrm{N}=3-4$ wells per experimental condition. (C) The control and arrHSC- 3 cells were wounded, and media were collected with their unwounded controls at $24 \mathrm{~h}$ and $48 \mathrm{~h}$. MMP9 and $-2 \mathrm{ex}-$ pression levels were analysed from cell culture media by zymography as described in methods. Purified gelatinase standards are shown on the right: proMMP9 (92 kDa), active MMP9 (82 kDa), pro-MMP2 (72 kDa) and active MMP2 (62 kDa) (A and C). P-values were calculated using Student's Ttest. * $\mathrm{p}<0.05, * * \mathrm{p}<0.01, * * *$ $\mathrm{p}<0.001$.
Finland, the Finnish Cultural Foundation, the Finnish Dental Society Apollonia, the Cancer Foundation of Northern Finland, the University of Oulu Scholarship Foundation and research funds from the Medical Faculty of the University of Oulu and Oulu University Hospital special state support for research.

\section{Conflict of interest}

The authors declare no competing financial interests.

\section{Appendix A. Supporting information}

Supplementary data associated with this article can be found in the online version at doi:10.1016/j.yexcr.2019.01.018.

\section{References}

[1] D. Marsh, K. Suchak, K.A. Moutasim, S. Vallath, C. Hopper, W. Jerjes, et al., Stromal features are predictive of disease mortality in oral cancer patients, J. Pathol. 223 (4) (2011) 470-481, https://doi.org/10.1002/path.2830.

[2] R. Mroueh, A. Haapaniemi, R. Grénman, J. Laranne, M. Pukkila, A. Almangush, et al., Improved outcomes with oral tongue squamous cell carcinoma in Finland, Head. Neck 39 (7) (2017) 1306-1312, https://doi.org/10.1002/hed.24744.

[3] J. Decock, S. Thirkettle, L. Wagstaff, D.R. Edwards, Matrix metalloproteinases: protective roles in cancer, J. Cell Mol. Med. 15 (6) (2011) 1254-1265, https://doi. org/10.1111/j.1582-4934.2011.01302.x.

[4] S.V. Thangaraj, et al., V. Shyamsundar, A. Krishnamurthy, P. Ramani, K. Ganesan, M. Muthuswami, Molecular portrait of oral tongue squamous cell carcinoma shown by integrative meta-analysis of expression profiles with validations, PLoS One 11 (6) (2016) ([cited 2018 Feb 22] Teh M-T, editor).

[5] S.-T. Vilen, T. Salo, T. Sorsa, P. Nyberg, Fluctuating roles of matrix metalloproteinase-9 in oral squamous cell carcinoma, Sci. World J. 2013 (2013) $920595<$ http:// www.pubmedcentral.nih.gov/articlerender.fcgi? artid $=3556887 \&$ tool $=$ pmcentrez \&rendertype $=$ abstract $>$.

[6] R.C.K. Jordan, M. Macabeo-Ong, C.H. Shiboski, N. Dekker, D.G. Ginzinger, D.T.W. Wong, et al., Overexpression of matrix metalloproteinase-1 and - 9 mRNA Is associated with progression of oral dysplasia to cancer, Clin. Cancer Res 10 (19) (2004) (6460 LP-6465). 〈http://clincancerres.aacrjournals.org/content/10/19/ 6460.abstract $>$.

[7] B.P. Patel, P.M. Shah, U.M. Rawal, A.A. Desai, S.V. Shah, R.M. Rawal, et al., Activation of MMP-2 and MMP-9 in patients with oral squamous cell carcinoma, J. Surg. Oncol. 90 (2) (2005) 81-88, https://doi.org/10.1002/jso.20240.

[8] A. Stokes, J. Joutsa, R. Ala-aho, M. Pitchers, C.J. Pennington, C. Martin, et al.,
Expression profiles and clinical correlations of degradome components in the tumor microenvironment of head and neck squamous cell carcinoma, Clin. Cancer Res. 16 (7) (2010) 2022-2035〈http://www.ncbi.nlm.nih.gov/pubmed/20305301〉.

[9] C.-W. Lin, S.-W. Tseng, S.-F. Yang, C.-P. Ko, C.-H. Lin, L.-H. Wei, et al., Role of lipocalin 2 and its complex with matrix metalloproteinase-9 in oral cancer, Oral. Dis. 18 (8) (2012) 734-740, https://doi.org/10.1111/j.1601-0825.2012.01938.x.

[10] P. Garg, D. Sarma, S. Jeppsson, N.R. Patel, A.T. Gewirtz, D. Merlin, et al., Matrix metalloproteinase- 9 functions as a tumor suppressor in colitis-associated cancer, Cancer Res. 70 (2) (2010) (792 LP-801), 〈http://cancerres.aacrjournals.org/ content/70/2/792.abstract $>$.

[11] E. Mylona, A. Nomikos, C. Magkou, M. Kamberou, I. Papassideri, A. Keramopoulos, et al., The clinicopathological and prognostic significance of membrane type 1 matrix metalloproteinase (MT1-MMP) and MMP-9 according to their localization in invasive breast carcinoma, Histopathol. 50 (3) (2007) 338-347, https://doi.org/10. 1111/j.1365-2559.2007.02615.x.

[12] P. Åström, K. Juurikka, E.S. Hadler-Olsen, G. Svineng, N.K. Cervigne, R.D. Coletta, et al., The interplay of matrix metalloproteinase-8, transforming growth factor[beta] 1 and vascular endothelial growth factor-C cooperatively contributes to the aggressiveness of oral tongue squamous cell carcinoma, Br. J. Cancer 117 (2017) 1007-1016, https://doi.org/10.1038/bjc.2017.249.

[13] P. Heikkilä, J. Suojanen, E. Pirilä, A. Väänänen, E. Koivunen, T. Sorsa, et al., Human tongue carcinoma growth is inhibited by selective antigelatinolytic peptides, Int. J. Cancer 118 (9) (2006) 2202-2209, https://doi.org/10.1002/ijc.21540.

[14] J. Suojanen, S.-T. Vilen, P. Nyberg, P. Heikkilä, O. Penate-Medina, P.E.J. Saris, et al., Selective gelatinase inhibitor peptide is effective in targeting tongue carcinoma cell tumors in vivo, Anticancer Res. 31 (11) (2011) 3659-3664 〈http://www. ncbi.nlm.nih.gov/pubmed/22110184>.

[15] E. Koivunen, W. Arap, H. Valtanen, A. Rainisalo, O.P. Medina, P. Heikkilä, et al., Tumor targeting with a selective gelatinase inhibitor, Nat. Biotechnol. 17 (8) (1999) 768-774〈http://www.ncbi.nlm.nih.gov/pubmed/10429241〉.

[16] P. Boukamp, Normal keratinization in a spontaneously immortalized aneuploid human keratinocyte cell line, J. Cell Biol. 106 (3) (1988 1) 761-771, https://doi. org/10.1083/jcb.106.3.761.

[17] M. Kylmäniemi, A. Oikarinen, K. Oikarinen, T. Salo, Effects of dexamethasone and cell proliferation on the expression of matrix metalloproteinases in human mucosal normal and malignant cells, J. Dent. Res. 75 (3) (1996) 919-926, https://doi.org/ 10.1177/00220345960750030901.

[18] D. Oda, L. Bigler, E.J. Mao, C.M. Disteche, Chromosomal abnormalities in HPV-16immortalized oral epithelial cells, Carcinog. 17 (9) (1996) 2003-2008 〈http:// www.ncbi.nlm.nih.gov/pubmed/8824527>.

[19] M. Aikio, I. Alahuhta, S. Nurmenniemi, J. Suojanen, R. Palovuori, S. Teppo, et al., Arresten, a Collagen-Derived Angiogenesis Inhibitor, Suppresses Invasion of Squamous Cell Carcinoma, PLoS One 7 (12) (2012) e51044, https://doi.org/10. 1371/journal.pone.0051044 (C.L. Addison, editor).

[20] U.B. Hofmann, J.R. Westphal, A.A. Van Kraats, D.J. Ruiter, G.N.P. Van Muijen, Expression of integrin $\alpha v \beta 3$ correlates with activation of membrane-type matrix metalloproteinase-1 (MT1-MMP) and matrix metalloproteinase-2 (MMP-2) in human melanoma cells in vitro and in vivo, Int. J. Cancer 87 (1) (2000) 12-19, 
https://doi.org/10.1002/1097-0215(20000701)87:1\%3C12::AID-IJC3\%3E3.0.CO.

[21] P. Nyberg, P. Heikkilä, T. Sorsa, J. Luostarinen, R. Heljasvaara, U.-H. Stenman, et al., Endostatin inhibits human tongue carcinoma cell invasion and intravasation and blocks the activation of matrix metalloprotease-2, -9, and -13, J. Biol. Chem. 278 (25) (2003 20) 22404-22411, https://doi.org/10.1074/jbc.M210325200.

[22] P. Åström, R. Heljasvaara, P. Nyberg, A. Al-Samadi, T. Salo, Human tumor tissuebased 3D In vitro invasion assays, : Methods Mol. Biol. (2018) 213-221, https://doi. org/10.1007/978-1-4939-7595-2_19.

[23] S. Nurmenniemi, T. Sinikumpu, I. Alahuhta, S. Salo, M. Sutinen, M. Santala, et al., A novel organotypic model mimics the tumor microenvironment, Am. J. Pathol. 175 (3) (2009) 1281-1291 〈http://linkinghub.elsevier.com/retrieve/pii/ S0002944010606372〉.

[24] S. Teppo, E. Sundquist, M. Vered, H. Holappa, J. Parkkisenniemi, T. Rinaldi, et al., The hypoxic tumor microenvironment regulates invasion of aggressive oral carcinoma cells, Exp. Cell Res. 319 (4) (2013) 376-389 〈http://linkinghub.elsevier. com/retrieve/pii/S0014482712004879>.

[25] T. Salo, M. Sutinen, E. Hoque Apu, E. Sundquist, N.K. Cervigne, C.E. de Oliveira, et al., A novel human leiomyoma tissue derived matrix for cell culture studies, BMC

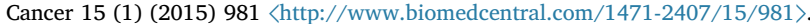

[26] J. Schindelin, I. Arganda-Carreras, E. Frise, V. Kaynig, M. Longair, T. Pietzsch, et al., Fiji: an open-source platform for biological-image analysis, Nat. Methods 9 (2012) 676, https://doi.org/10.1038/nmeth.2019.

[27] G. Dennis, B.T. Sherman, D.A. Hosack, J. Yang, W. Gao, H.C. Lane, et al., DAVID: database for annotation, visualization, and integrated discovery, Genome Biol. 4 (5) (2003) P3, https://doi.org/10.1186/gb-2003-4-5-p3.

[28] M. Rolli, E. Fransvea, J. Pilch, A. Saven, B. Felding-Habermann, Activated integrin alphavbeta3 cooperates with metalloproteinase MMP-9 in regulating migration of metastatic breast cancer cells, Proc. Natl. Acad. Sci. USA 100 (16) (2003) 9482-9487〈http://www.ncbi.nlm.nih.gov/pubmed/12874388〉.

[29] C. Mehner, A. Hockla, E. Miller, S. Ran, D.C. Radisky, E.S. Radisky, Tumor cellproduced matrix metalloproteinase 9 (MMP-9) drives malignant progression and metastasis of basal-like triple negative breast cancer, Oncotarget (2014).

[30] S.Y. Jang, A. Kim, J.K. Kim, C. Kim, Y.H. Cho, J.H. Kim, et al., Metformin inhibits tumor cell migration via down-regulation of MMP9 in tamoxifen-resistant breast cancer cells, Anticancer Res. (2014).

[31] J.P. Wang, A. Hielscher, Fibronectin: How its aberrant expression in tumors may improve therapeutic targeting, J. Cancer 8 (4) (2017) 674-682 〈http://www. jcancer.org/v08p0674.htm>.

[32] A. Dufour, S. Zucker, N.S. Sampson, C. Kuscu, J. Cao, Role of matrix metalloproteinase-9 Dimers in cell migration, J. Biol. Chem. [Internet] 285 (46) (2010) 35944-35956 〈http://www.ncbi.nlm.nih.gov/pmc/articles/PMC2975217/〉.

[33] K. Matsumoto, K. Matsumoto, T. Nakamura, R.H. Kramer, Hepatocyte growth factor/scatter factor induces tyrosine phosphorylation of focal adhesion kinase (p125FAK) and promotes migration and invasion by oral squamous cell carcinoma cells, J. Biol. Chem. 269 (50) (1994) 31807-31813 〈http://www.ncbi.nlm.nih.gov/ pubmed/7527397>.

[34] F. Momose, T. Araida, A. Negishi, H. Ichijo, S. Shioda, S. Sasaki, Variant sublines with different metastatic potentials selected in nude mice from human oral squamous cell carcinomas, J. Oral. Pathol. Med. 18 (7) (1989) 391-395, https://doi.org/ 10.1111/j.1600-0714.1989.tb01570.x.

[35] M. Laaksonen, J. Suojanen, S. Nurmenniemi, E. Läärä, T. Sorsa, T. Salo, The enamel matrix derivative (Emdogain ${ }^{\circledast}$ ) enhances human tongue carcinoma cells gelatinase production, migration and metastasis formation, Oral Oncol. 44 (8) (2008) 733-742 http://www.sciencedirect.com.pc124152.oulu.fi:8080/science/article/pii/ S1368837507002515?via\%3Dihub.

[36] E. Pirilä, O. Väyrynen, E. Sundquist, K. Päkkilä, P. Nyberg, S. Nurmenniemi, et al., Macrophages modulate migration and invasion of human tongue squamous cell carcinoma, PLoS One 10 (3) (2015).

[37] P. Kamarajan, A. Garcia-Pardo, N.J. D'Silva, Y.L. Kapila, The CS1 segment of fibronectin is involved in human OSCC pathogenesis by mediating OSCC cell spreading, migration, and invasion, BMC Cancer 10 (1) (2010) 330, https://doi. org /10.1186/1471-2407-10-330.

[38] E. Sundquist, J.H. Kauppila, J. Veijola, R. Mroueh, P. Lehenkari, S. Laitinen, et al., Tenascin-C and fibronectin expression divide early stage tongue cancer into low- and high-risk groups, Br. J. Cancer 116 (5) (2017) 640-648 〈http://www.ncbi.nlm. nih.gov/pmc/articles/PMC5344290/>.

[39] T. Sen, A. Dutta, G. Maity, A. Chatterjee, Fibronectin induces matrix metalloproteinase-9 (MMP-9) in human laryngeal carcinoma cells by involving multiple signaling pathways, Biochimie 92 (10) (2010) 1422-1434 〈http://linkinghub.elsevier.

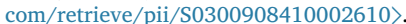

[40] G. Maity, P.R. Choudhury, T. Sen, K.K. Ganguly, H. Sil, A. Chatterjee, Culture of human breast cancer cell line (MDA-MB-231) on fibronectin-coated surface induce pro-matrix metalloproteinase-9 expression and activity, Tumor Biol. 32 (1) (2011) 129-138, https://doi.org/10.1007/s13277-010-0106-9.

[41] M. Matsuo, H. Sakurai, Y. Ueno, O. Ohtani, I. Saiki, Activation of MEK/ERK and PI3K/Akt pathways by fibronectin requires integrin av-mediated ADAM activity in hepatocellular carcinoma: a novel functional target for gefitinib, Cancer Sci. 97 (2) (2006) 155-162.

[42] D. Qin, G. Zhang, X. Xu, L. Wang, The PI3K/Akt signaling pathway mediates the high glucose-induced expression of extracellular matrix molecules in human retinal pigment epithelial cells, J. Diabetes Res. 2015 (2015) 1-11 〈http://www.ncbi.nlm. nih.gov/pmc/articles/PMC4324947/>.

[43] J. Luo, B.D. Manning, L.C. Cantley, Targeting the PI3K-Akt pathway in human cancer, Cancer Cell 4 (4) (2003) 257-262 〈http://linkinghub.elsevier.com/ retrieve/pii/S1535610803002484>.

[44] E. Massarelli, D.D. Liu, J.J. Lee, A.K. El-Naggar, L. Lo Muzio, S. Staibano, et al., Akt activation correlates with adverse outcome in tongue cancer, Cancer 104 (11) (2005) 2430-2436, https://doi.org/10.1002/cncr.21476.

[45] J. Zhang, H.J. Wen, Z.M. Guo, M.S. Zeng, M.Z. Li, Y.E. Jiang, et al., TRB3 overexpression due to endoplasmic reticulum stress inhibits AKT kinase activation of tongue squamous cell carcinoma, Oral. Oncol. 47 (10) (2011) 934-939.

[46] E. Hadler-Olsen, B. Fadnes, I. Sylte, L. Uhlin-Hansen, J.-O. Winberg, Regulation of matrix metalloproteinase activity in health and disease, FEBS J. 278 (1) (2011) 28-45, https://doi.org/10.1111/j.1742-4658.2010.07920.x\%5C http://www.ncbi. nlm.nih.gov/pubmed/21087458.

[47] C.M. Overall, O. Kleifeld, Validating matrix metalloproteinases as drug targets and anti-targets for cancer therapy, Nat. Rev. Cancer 6 (2006) 227, https://doi.org/10 1038/nrc1821.

[48] H. Ruokolainen, P. Pääkkö, T. Turpeenniemi-Hujanen, Serum matrix metalloproteinase-9 in head and neck squamous cell carcinomais a prognostic marker, Int. J. Cancer 116 (3) (2005) 422-427, https://doi.org/10.1002/ijc.21092.

[49] M. Groblewska, M. Siewko, B. Mroczko, M. Szmitkowski, The role of matrix metalloproteinases (MMPs) and their inhibitors (TIMPs) in the development of esophageal cancer, Folia Histochem Cytobiol. 50 (1) (2012) 12-19〈http://czasopisma. viamedica.pl/fhc/article/view/18691>.

[50] S. Schäfer, S. Weibel, U. Donat, Q. Zhang, R.J. Aguilar, N.G. Chen, et al., Vaccinia virus-mediated intra-tumoral expression of matrix metalloproteinase 9 enhances oncolysis of PC-3 xenograft tumors, BMC Cancer 12 (1) (2012) 366, https://doi. org/10.1186/1471-2407-12-366.

[51] K.S. Leifler, S. Svensson, A. Abrahamsson, C. Bendrik, J. Robertson, J. Gauldie, et al., Inflammation induced by MMP-9 enhances tumor regression of Experimental breast cancer, J. Immunol. 190 (8) (2013) 4420-4430 〈http://www. pubmedcentral.nih.gov/articlerender.fcgi? artid $=3619527 \&$ tool $=$ pmcentrez\& rendertype $=$ abstract $>$.

[52] M.D. Martin, L.M. Matrisian, The other side of MMPs: protective roles in tumor progression, Cancer Metastas-. Rev. 26 (3-4) (2007 24) 717-724, https://doi.org/ 10.1007/s10555-007-9089-4.

[53] L.M. Coussens, C.L. Tinkle, D. Hanahan, Z. Werb, MMP-9 supplied by bone marrowderived cells contributes to skin carcinogenesis, Cell [Internet]. 103 (3) (2000) 481-490〈http://www.ncbi.nlm.nih.gov/pubmed/11081634〉.

[54] S.-H. Kim, N.H. Cho, K. Kim, J.S. Lee, B.S. Koo, J.H. Kim, et al., Correlations of oral tongue cancer invasion with matrix metalloproteinases (MMPs) and vascular endothelial growth factor (VEGF) expression, J. Surg. Oncol. [Internet]. 93 (4) (2006) 330-337, https://doi.org/10.1002/jso.20461.

[55] J.T. Korpi, V. Kervinen, H. Mäklin, A. Väänänen, M. Lahtinen, E. Läärä, et al., Collagenase-2 (matrix metalloproteinase-8) plays a protective role in tongue cancer, Br. J. Cancer 98 (2008) 766, https://doi.org/10.1038/sj.bjc.6604239. 